\title{
(2) OPEN ACCESS \\ Low-income and middle-income countries leading the way with tobacco control policies
}

\author{
Joanna E Cohen (D) ,' Graziele Grilo, ${ }^{1}$ Lauren Czaplicki, ${ }^{1}$ \\ Jennifer L Brown (D) ,' Kevin Welding (D) ,' Marita Hefler, ${ }^{2}$ \\ Ryan D Kennedy, ${ }^{1}$ Anne-Marie Perucic ${ }^{3}$
}

'Department of Health, Behavior and Society, Johns Hopkins University Bloomberg School of Public Health, Baltimore, Maryland, USA

${ }^{2}$ Menzies School of Health Research, Charles Darwin University, Casuarina, Northern Territory, Australia

${ }^{3}$ Health Promotion Department, WHO, Geneva, Switzerland

\section{Correspondence to}

Dr Joanna E Cohen, Department of Health, Behavior and Society, Johns Hopkins University Bloomberg School of Public Health, Baltimore, MD 21205, USA; jcohen@jhu.edu

Accepted 20 December 2021 Published Online First

17 January 2022
A Check for updates

(c) Author(s) (or their employer(s)) 2022. Re-use permitted under CC BY-NC. No commercial re-use. See rights and permissions. Published by BMJ.

To cite: Cohen JE, Grilo G, Czaplicki L, et al. BMJ Innov 2022;8:4-8.

\section{GLOBAL TOBACCO USE AND POLICY INTERVENTIONS}

Tobacco products are the world's single largest cause of preventable death, accounting for more than 8 million deaths each year and causing suffering from avoidable illnesses among tens of millions more. ${ }^{1}$ Tobacco-caused death and disease disproportionately affects people in low-income and middle-income countries (LMICs). ${ }^{1}{ }^{2}$ The WHO Framework Convention on Tobacco Control (FCTC), with 182 parties from all regions of the world, was developed in response to the globalisation of the tobacco epidemic and lays out evidence-based demand and supply reduction strategies. These strategies have resulted in measurable progress: global cigarette sales have been declining since 2012 despite overall population growth. ${ }^{1}$ It is estimated that tobacco control interventions have saved more than 37 million lives ${ }^{1}$ as fewer people start and more people quit, using tobacco products. However, there is much more work needed ahead. Over 1 billion people worldwide still use tobacco products, ${ }^{2}$ and the tobacco industry continues to aggressively fight the enactment and effective implementation of proven policy interventions. ${ }^{3}$

The demand and supply measures outlined in the FCTC, adopted by the World Health Assembly in 2003, are considered a floor (after all, the Framework Convention was based on the best evidence available through the dawn of the 21st century). However, FCTC Article 2.1 explicitly encourages countries to go beyond the measures outlined, and they have! Early tobacco control policy innovations, with data of their impacts feeding into the development of the FCTC, included smoke-free air policies in states and cities in the USA, pictorial health warning labels (HWLs) in Canada, restrictions on tobacco advertising and sponsorship in Canada, and the use of tobacco excise taxes as a measure to reduce smoking in Canada. Since the FCTC came into force, innovations have included a ban on the display of tobacco products at the point of sale in Iceland, and plain and standardised packaging in Australia.

However, policy innovations have also occurred across LMICs. This commentary highlights seven diverse examples from across the globe, selected by the authors, of world precedent setting, first-of-their kind interventions that have originated in LMICs.

\section{SEVEN TOBACCO CONTROL POLICY INNOVATIONS IN LMICS \\ Large HWLs on cigarette packs}

Article 11 of the FCTC recommends pictorial HWLs that cover at least 50\% of the front and back panels of tobacco product packaging, with periodic rotation to maintain saliency and enhance impact. ${ }^{4}$ HWLs are an important and low-cost mechanism to communicate the dangers of tobacco use, particularly given their visibility; HWLs may be viewed by pack-a-day smokers over 7000 times a year. ${ }^{5}$ As tobacco advertising at points of sale, on television, in magazines and other places have become restricted or banned in many countries, tobacco packaging remains a way for tobacco companies to attract new users and keep current ones. However, the larger the HWL, the less 
space available for the tobacco industry to market on product packaging.

LMICs have been at the forefront of employing large pictorial HWLs. A 2013 policy made the 85\% pictorial HWLs in Thailand the largest in the world. ${ }^{6}$ Nepal surpassed Thailand in 2015 with 90\% pictorial HWLs; India matched Thailand with $85 \%$ pictorial HWLs in 2016; and Vanuatu rose to equal top spot with $90 \%$ pictorial HWLs in 2017.6 7 In 2018, Timor-Leste became the world leader with an average of $92.5 \%$ pictorial HWL coverage (front: 85\%, back: 100\%). ${ }^{7}$ Currently, there are 18 countries with pictorial HWLs that cover $75 \%$ or more of the front and back panels of cigarette packs, and 3 LMICs (Timor-Leste, Nepal and Maldives) are the world leaders with an average of $90 \%$ or more coverage on the main panels. ${ }^{8}$

\section{Single brand presentation}

The tobacco industry has historically used brand variant names to mislead consumers and reinforce that one brand variant (eg, Marlboro Light) may be less harmful than another (eg, Marlboro Red). ${ }^{9}$ In 2008, Uruguay became the first country to adopt a single brand presentation standard for cigarettes. ${ }^{10}$ This policy restricts the ability of tobacco companies to sell multiple brand variants (eg, Marlboro Red, Marlboro Medium and Marlboro Light) in the country. Instead, only a single presentation or variant per brand can be sold.

Uruguay also implemented a plain packaging standard in 2019, whereby all cigarette packs must be sold without any product branding and in the same colour with the brand name appearing in the same font and position on every pack. ${ }^{11}$ The plain packaging requirement works together with the single brand variant standard to further limit the tobacco industry's ability to use pack colour, text descriptors, and brand imagery to attract new and established consumers; they also limit the tobacco industry's efforts to convey a product is lower risk through the use of lighter colours (eg, silver) or text descriptors (eg, 'ultralight'). Further, the novel combination of these policies addresses an important plain packaging policy loophole. In countries like Australia-where only a plain packaging requirement exists-tobacco companies manipulate the brand variant name by including a colour or other descriptor (eg, Dunhill Distinct Blue and Pall Mall Rich Blue) to associate the variant with the pack colour or appearance prior to the law. ${ }^{12}$

Uruguay's pioneering approach of layering the single brand presentation and plain packaging standard reduces the potential for tobacco industry branding and variant marketing tactics to attract and mislead consumers.

\section{Additive ban}

The use of flavours and other additives has been a key strategy of the tobacco industry to mask the harshness of tobacco and facilitate its consumption. ${ }^{13}$ In 2012 , Brazil became the first country in the world to pass a comprehensive additive ban for all tobacco products ${ }^{14}$ (including electronic cigarettes and heated tobacco products) with the intent to decrease product palatability and appeal, and reduce initiation. ${ }^{15}$

The resolution established by the Brazilian Health Regulatory Agency (Anvisa) defined additive as any substance or compound other than tobacco or water used in the processing, manufacturing and/or packaging of tobacco products, including flavours ${ }^{16}$; this includes any additive that can impart, intensify, modify or enhance the taste and smell of tobacco. ${ }^{16}$ Brazil's ban is also the first to include menthol as a banned flavour (previous national flavour additive bans in Canada and the USA exempted menthol). ${ }^{14}$ The comprehensive list of banned additives includes synthetic and natural substances, as well as flavouring agents identified by the Joint FAO/WHO Expert Committee on Food Additives or by the Flavour and Extract Manufacturers Association. $^{16}$

After almost a decade, the ban has yet to be implemented due to several lawsuits filed by the tobacco industry and its allies that challenged the constitutionality of Anvisa's regulatory powers and the additive ban. In 2018, the Federal Supreme Court ruled in favour of Anvisa and the ban in a non-binding decision, but at the time of writing, active lawsuits in other courts are pending decisions. The Supreme Court ruling was reaffirmed in two recent decisions against SindiTabaco (Union Interstate of the Tobacco Industry), which represents the major tobacco companies in Brazil. SindiTabaco has appealed both decisions, and the implementation of the ban remains stalled.

\section{Banning sales of a prevalent smokeless tobacco (SLT) product}

In India, like other countries in South Asia, SLT is the most common form of tobacco consumed and contributes to ongoing public health challenges, including high rates of oral cancers. Results from the 2009-2010 India Global Adult Tobacco Use Survey revealed that $26 \%$ of the population-or 206 million people-used SLT (33\% men, 18\%women). ${ }^{17}$ Among those users, 65 million used the SLT product gutka (53.9 million men and 11.1 million women. ${ }^{17}$ Gutka is a mixture of tobacco, areca or betel nut, slaked lime and spices/ sweeteners, commonly sold in colourful packets.

In India, a Supreme Court judgement determined that federal food laws prohibited the presence of tobacco in food products, and regulations to this effect were issued in 2011. Beginning in 2012, with the state of Madhya Pradesh's ban, all states in India now ban tobacco-containing and nicotine-containing gutka products. ${ }^{18}$ The tobacco industry challenged the decision to classify gutka as a food and challenged states' regulatory authority to ban tobacco products using food laws. ${ }^{19}$ While gutka remains banned in India, the 
tobacco industry has introduced new 'twin pack' products which separate tobacco from the other constituents of gutka for the user to mix once purchased.

There is no precedent for a policy that bans a tobacco product used by 65 million people. Some jurisdictions had previously banned SLT, such as Hong Kong in 1987 and Australia in 1991, and continue to restrict sales of SLT products; however, this was done before any sizeable market existed in these jurisdictions. While banning SLT is an important precedent, it highlights the need to also aggressively address combustible tobacco products.

\section{Strengthening penalties for illicit trade in tobacco products}

The risk of increased illicit trade in tobacco products has been a common argument used by the tobacco industry to counter effective tobacco control interventions, including raising tobacco taxes. However, countless studies and country experiences have shown that strengthening tax administration is the best way to counter illicit trade. ${ }^{20}$

One tax administration approach to deter criminal activity is the implementation of sanctions and penalties. ${ }^{20}$ In a series of efforts to combat illicit trade, Colombia reformed its criminal code in 2015 and introduced Law 1762 to prevent, control and punish smuggling, money laundering and tax evasion. This new law hardened the penalties on illicit trade, making it an offence similar to money laundering. Among the provisions introduced, the prison sentences for offenders increased from 3 years to 5 years to $4-12$ years. Prison sentences also applied to government officials involved in illicit trade and any individuals involved in the transport and retail of those products. New sanctions for tobacco tax evasion were also introduced such as seizure of goods, closure of retail shops, and suspension or cancellation of licences. ${ }^{20} 21$ To increase the likelihood of arrests, the authorities strengthened coordination of legal enforcement agencies through the establishment of a special interagency commission to spearhead information sharing and coordination planning. ${ }^{21}$ In only 2 years following these concerted actions, a number of criminal organisations were dismantled; assets were confiscated; and thousands of individuals were apprehended. ${ }^{20}$ These actions set a global precedent for treating the illicit trade of tobacco products as the serious crime that it is.

\section{Tobacco-free generation}

A policy banning tobacco sales to citizens born after a specific year was first proposed by researchers in Singapore in 2010, citing strong support by Singaporean citizens. ${ }^{22}$ In 2011, youth advocates mobilised to form a non-profit to promote what is now formally known as the Tobacco Free Generation (TFG) ${ }^{23}$ initiative and widely recognised as a tobacco endgame strategy. TFG is expected to overcome the challenges of enforcement of restriction on tobacco sales to minors and address reasons why these policies have not fully achieved their objectives. ${ }^{22}{ }^{24}$ Further, a study modelling the impacts of various tobacco control policies using New Zealand as a case study found that implementing TFG would result in substantial reductions in smoking prevalence. $^{25}$

In 2016, Balanga City in the Philippines was the first jurisdiction to enact TFG as it was initially conceptualised. ${ }^{26}$ The Tobacco Free Generation End Game Strategy Ordinance specifically bans the sale and use of tobacco products and electronic cigarettes to anyone born on or after 1 January $2000 .{ }^{26}$ In 2017 and 2018, the Philippine Tobacco Institute filed lawsuits to thwart implementation of the TFG bill in Balanga City on the grounds that national regulations preempt the policy. The lawsuits are still pending at the time of writing. A TFG bill was tabled in the Tasmanian Parliament in Australia in 2014 but lapsed in 2018 .

\section{Banning tobacco company corporate social responsibility (CSR)}

CSR programmes are powerful tools for the tobacco industry to undermine and circumvent the policy interventions put forward by the FCTC. Where direct advertising is banned, CSR activities can function as an alternative form of marketing for tobacco companies, ${ }^{27}$ helping the tobacco industry to improve its public image, nurture allies and cultivate political influence to undermine policy making. ${ }^{28}$

Tobacco company CSR activities are addressed by FCTC Article 5.3, which aims to protect tobacco control policies from tobacco industry interference, and Article 13, which bans all forms of advertising, sponsorship and promotion. ${ }^{28}$ Despite FCTC implementation guidelines explicitly recommending tobacco industry CSR be prohibited, ${ }^{29}$ a 2016 study of tobacco industry websites found CSR activities mentioned in 58 countries, most of which were parties to the FCTC. ${ }^{28}$

In 2008, Mauritius became a world leader in introducing a comprehensive and strongly enforced ban on tobacco industry CSR activities. ${ }^{29}$ The ban was enacted through an amendment to its 1999 Public Health Act. It prevented all forms of sponsorship for events, activities or individuals intended or likely to directly or indirectly promote a tobacco product or tobacco use; prohibited promotions of tobacco trademarks, manufacturers, logos or brand names; and banned scholarships or any other form of sponsorship associated with tobacco products. ${ }^{29}$ Mauritius' comprehensive policy stands as an important global precedent. The WHO Global Health Observatory lists 26 countries which had bans on tobacco industry CSR in place in 2008; by 2018 , this had increased to 63 , of which over $50 \%$ were LMICs. ${ }^{30}$ 


\section{LOOKING TO LMICs FOR INSPIRATION}

It is encouraging and inspiring that innovation in tobacco control policy interventions continues to occur across the world, including in LMICs. The policies we highlight here demonstrate global leadership by LMICs in four of the six WHO regions. High-income countries should follow the lead of these LMICs and be more aggressive in both adopting and enforcing tobacco control policies. It is essential that jurisdictions continue to implement new and stronger policies so the "dose" of these critical interventions does not wane with time.

The FCTC is a revolutionary blueprint for action that countries must implement (and continue to innovate on) to improve the health of their populations for generations to come. Continued innovation is indeed part of the FCTC's DNA, with Article 2.1 explicitly encouraging countries to go beyond its provisions. The world has suffered from the industrial tobacco epidemic for far too long. It is time to end it.

Twitter Jennifer L Brown @jenniferlynette, Kevin Welding @ kevinmwelding and Anne-Marie Perucic@amperucic

Contributors All authors contributed to writing and reviewing the paper and approved the final version. JEC is the corresponding author and takes responsibility for the overall content as guarantor.

Funding JEC, GG, LC, JLB, KW and RDK are supported by a grant from Bloomberg Philanthropies through the Bloomberg Initiative to Reduce Tobacco Use. $\mathrm{MH}$ is the recipient of a Gender Equity Fellowship from the Menzies School of Health Research, Darwin, Australia. She also receives salary support from the Australian National Health \& Medical Research Council grant (GNT1198301), Centre for Research Excellence on Achieving the Tobacco Endgame through the University of Queensland.

Competing interests None declared.

Patient consent for publication Not applicable.

Ethics approval This study does not involve human participants.

Provenance and peer review Not commissioned; externally peer reviewed.

Open access This is an open access article distributed in accordance with the Creative Commons Attribution Non Commercial (CC BYNC 4.0) license, which permits others to distribute, remix, adapt, build upon this work non-commercially, and license their derivative works on different terms, provided the original work is properly cited, appropriate credit is given, any changes made indicated, and the use is non-commercial. See: http://creativecommons.org/ licenses/by-nc/4.0/.

\section{ORCID iDs}

Joanna E Cohen http://orcid.org/0000-0002-3869-3637 Jennifer L Brown http://orcid.org/0000-0001-7418-1172

Kevin Welding http://orcid.org/0000-0002-1833-6691

\section{REFERENCES}

1 World Health Organization. WHO report on the global tobacco epidemic 2021: addressing new and emerging products, 2021. Available: https://www.who.int/publications/i/ item/9789240032095

2 Reitsma MB, Flor LS, Mullany EC, et al. Spatial, temporal, and demographic patterns in prevalence of smoking tobacco use and initiation among young people in 204 countries and territories, 1990-2019. Lancet Public Health 2021;6:e472-81.
3 Ulucanlar S, Fooks GJ, Gilmore AB. The policy dystopia model: an interpretive analysis of tobacco industry political activity. PLoS Med 2016;13:e1002125.

4 World Health Organization. Guidelines for implementation of article 11 of the who framework convention on tobacco control (packaging and labelling of tobacco products), 2008. Available: http://www.who.int/fctc/guidelines/article_11.pdf? ua $=1$

5 Hammond D. Health warning messages on tobacco products: a review. Tob Control 2011;20:327-37.

6 Canadian Cancer Society. Cigarette package health warnings: international status report. Fifth ed, 2016. https:// tobaccolabels.s3.ca-central-1.amazonaws.com/uploads/2016/ 11/Cigarette-Package-Health-Warnings-International-StatusReport-English-CCS-Oct-2016.pdf

7 Canadian Cancer Society. Cigarette package health warnings: international status report. Sixth ed, 2018. https://www. tobaccofreekids.org/assets/global/pdfs/en/WL_status_report_en. pdf

8 Campaign for Tobacco-Free Kids. Tobacco Control Laws. Available: https://www.tobaccocontrollaws.org/legislation/ finder/\#_packwarning-tab [Accessed 10 Sep 2021].

9 DeAtley T, Bianco E, Welding K, et al. Compliance with Uruguay's single presentation requirement. Tob Control 2018;27:220-4.

10 Ministry of Public Health. Uruguay ordinance no. 466, 2009. Available: https://www.tobaccocontrollaws.org/files/live/ Uruguay/Uruguay\%20-\%20Ordinance\%20No.\%20466.pdf [Accessed 09 Sep 2021].

11 Oriental Republic of Uruguay. Law no. 19.723, 2019. Available: https://www.tobaccocontrollaws.org/files/live/ Uruguay/Uruguay\%20-\%20Law\%20No.\%2019.723.pdf [Accessed 09 Sep 2021].

12 Wakefield M, Coomber K, Zacher M, et al. Australian adult smokers' responses to plain packaging with larger graphic health warnings 1 year after implementation: results from a national cross-sectional tracking survey. Tob Control 2015;24:ii17-25.

13 World Health Organization. Partial guidelines for implementation of articles 9 and 10, 2017. Available: https:// www.who.int/fctc/treaty_instruments/guidelines_articles_9_10_ 2017_english.pdf [Accessed 03 Sep 2021].

14 Erinoso O, Clegg Smith K, Iacobelli M, et al. Global review of tobacco product flavour policies. Tob Control 2021;30:373-9.

15 Agência Nacional de Vigilância Sanitária - Anvisa. Regulamentação. Available: https://www.gov.br/anvisa/pt-br/ assuntos/tabaco/aditivos/regulamentacao [Accessed 03 Sep 2021].

16 Ministério da Saúde. Agência Nacional de Vigilância Sanitária. Resolução da diretoria colegiada - RDC no 14, de 15 março de 2012. Dispõe sobre os limites máximos de alcatrão, nicotina e monóxido de carbono nos cigarros e a restrição do uso de aditivos nos produtos fumígenos derivados do tabaco, e dá outras providências., 2012. Available: https://bvsms.saude. gov.br/bvs/saudelegis/anvisa/2012/rdc0014_15_03_2012.pdf [Accessed 03 Sep 2021].

17 Gupta PC, Arora M, Sinha D, et al. Smokeless tobacco and public health in India. New Delhi, India: Ministry of Health \& Family Welfare, Government of India, 2016.

18 Kumar G, Pednekar MS, Narake S, et al. Feedback from vendors on gutka ban in two States of India. Indian J Med Res 2018;148:98. 


\section{Discussion}

19 Dsouza R, Bhojani U. Strategic and contested us of food laws to ban smokeless tobacco products in India: a qualitative analysis of litigation. To $b$ Control 2021:tobaccocontrol-056241.

20 World Health Organization. WHO technical manual on tobacco Tax policy and administration, 2021. Available: https:// www.who.int/publications/i/item/9789240019188 [Accessed 10 Sep 2021].

21 Cardenas M. Case studies in illicit tobacco trade: Colombia. Tobacconomics fact sheet, 2020. Available: https:// tobacconomics.org/files/research/606/UIC_Colombia-IllicitTrade-Fact-Sheet_v1.4.pdf

22 Khoo D, Chiam Y, Ng P, et al. Phasing-out tobacco: proposal to deny access to tobacco for those born from 2000. Tob Control 2010;19:355-60.

23 David AM, Mercado SP, Klein JD, et al. Protecting children and families from tobacco and tobacco-related NCDs in the Western Pacific: good practice examples from Malaysia, Philippines and Singapore. Child Care Health Dev 2017;43:774-8.

24 Berrick AJ. The tobacco-free generation proposal. Tob Control 2013;22 Suppl 1:i22-6.

25 van der Deen FS, Wilson N, Cleghorn CL, et al. Impact of five tobacco endgame strategies on future smoking prevalence, population health and health system costs: two modelling studies to inform the tobacco endgame. To $b$ Control 2018;27:278-86.

26 de Leon K, Sarita JT. The Philippines: pioneering the tobacco endgame. tobacco control web site, 2020. Available: https:// blogs.bmj.com/tc/2020/01/13/the-philippines-pioneering-thetobacco-endgame/ [Accessed 11 Sep 2021].

27 Collin J, Ralston R, Hill S. Signaling virtue, promoting harm: unhealthy commodity industries and covid-19, 2020. Available: https://ncdalliance.org/sites/default/files/resource_files/ Signalling\%20Virtue\%2C\%20Promoting\%20Harm_Sept 2020 FINALv.pdf [Accessed 06 Sep 2021].

28 McDaniel PA, Cadman B, Malone RE. Shared vision, shared vulnerability: a content analysis of corporate social responsibility information on tobacco industry websites. Prev Med 2016;89:337-44.

29 Assunta M. Good country practices in the implementation of WHO FCTC article 5.3 and its guidelines., 2018. Available: https://www.who.int/fctc/publications/fctc-article-5-3-bestpractices.pdf [Accessed 06 Sep 2021].

30 Global Health Observatory. Ban on corporate social responsibility activities (CSR). Available: https://www.who.int/ data/gho/data/indicators/indicator-details/GHO/gho-tobaccocontrol-enforce-bans-e17a-csr-ban- [Accessed 06 Sep 2021]. 